Archaeologia Historica Polona tom 26, 2018, ISSN 1425-3534

Instytut Archeologii

Uniwersytet Rzeszowski

http://dx.doi.org/10.12775/AHP.2018.016

PAWEL KOCAŃDA

\title{
Z problematyki badawczej zamków biskupa Jana Muskaty w ziemi krakowskiej
}

\section{On the research problems of the castles of Bishop Jan Muskata in Krakow Land}

\begin{abstract}
Zarys treści. Biskup krakowski Jan Muskata należy do postaci kontrowersyjnych w polskiej historiografii. Zasłynął jako największy stronnik Wacława II króla czeskiego, panującego w latach 1291-1305 i zagorzały przeciwnik Władysława Łokietka. Prowadził intensywną działalność polityczną i fundacyjną, czego dowodem są zbudowane lub rozbudowane przez niego zamki w ziemi krakowskiej. W toku obecnych badań wiązać z nim należy między innymi warownie w Sławkowie, Lipowcu, Przymiłowicach, Muszynie i Kurowie nad Dunajcem. Celem tak licznych inwestycji obronnych było nie tylko umocnienie panowania Wacława II czeskiego, ale również stworzenie odrębnego władztwa terytorialnego w postaci księstwa biskupiego Jana Muskaty.
\end{abstract}

Słowa kluczowe: biskup krakowski, Jan Muskata, Małopolska, Wacław II, władztwo terytorialne, zamki.

Profesor Leszek Kajzer, którego pamięci poświęcono konferencję naukową pt. „Zamki - signum temporis medii aevi”, w swych rozlicznych publikacjach dotyczących budownictwa warownego na ziemiach polskich, wielokrotnie poruszał kwestie fundacji biskupich (Kajzer 1983, s. 147-158; 1990; 1994, s. 281-298; 1997, s. 7-14). Problematyka ta została podjęta także przez innych badaczy (m.in. Proksa 1994, s. 294-299; Kołodziejski 1995, s. 135-149; 2016, s. 807-825; Marciniak-Kajzer 1996, s. 97-110; Pietrzak 2000, s. 107-134; Brzostowska 2001, s. 53-57; Lasek 2013, s. 54-60, 118-125), a nawet poświęcono jej jedną z konferencji naukowych pt. „Siedziby biskupów krakowskich”, która odbyła się w Kielcach w 1997 roku (Siedziby biskupów krakowskich 1997). Zamki wznoszone przez osoby duchowne, a więc biskupów lub szerzej - Kościół, należą - obok fundacji monarszych 
i prywatnych - do obiektów obronnych istniejących w rzeczywistości feudalnej (Kajzer, Kołodziejski, Salm 2010, s. 22). Zagadnienie to jest o tyle ważne, że to właśnie Kościołowi wielu badaczy przypisuje przełamanie regale grodowego, co w konsekwencji doprowadziło do wytworzenia się kategorii prywatnych zamków możnowładczych. Początku tych wydarzeń doszukiwać się trzeba w przemianach społeczno-ustrojowych, które nastąpiły w XII stuleciu oraz otrzymaniu przez Kościół sporych nadań ziemskich w postaci kasztelanii majątkowych wraz z wieloma prawami, jakie dotychczas przysługiwały tylko panującemu. W obrębie nadań ziemskich znajdowały się liczne grody kasztelańskie, które także przejęte zostały przez duchownych. Dysponując tak szerokimi uprawnieniami Kościół nie tylko wzmocnił pozyskane grody, ale również rozpoczął budowę nowych (Modzelewski 1980, s. 449-477; Kołodziejski 1986, s. 16-18; 1992, s. 275-282; 1994, s. 171-172). Przykładów takiego postępowania możemy doszukiwać się chociażby na terenie Małopolski, gdzie w 2. połowie XIII wieku wzniesiono zamki w Sławkowie, Iłży i Lipowcu. Jednym z najbardziej aktywnych na tym polu biskupów krakowskich był Jan zwany Muskatą.

Postać Jana Muskaty była już szeroko prezentowana w polskiej literaturze naukowej, zarówno pod kątem biograficznym (Kozłowska-Budkowa 1976, s. 445-453; Wyrozumski 1977, s. 291-295; Pietras 2001a, s. 5-25; Maciejowski 2003, s. 93-111), jak i jego działalności kościelnej i politycznej (Kocańda 2016, s. 185-196-tam dalsza literatura). Najpełniejszym jak dotąd opracowaniem postaci duchownego jest praca Tomasza Pietrasa (2001b). Na stolec biskupi wybrany został - jak wykazały badania Andrzeja Rodziewicza (1995, s. 130-136) - w 1294 roku jako następca Prokopa. Przez większą część swojej kariery politycznej i duchownej, w okresie sprawowania urzędu związany był z Czechami, szczególnie Wacławem II, dla którego był największym sojusznikiem w Małopolsce (Nowakowski 1991, s. 1-13-25; Pietras 2001b, s. 43-86). Jednocześnie z funkcją infułata dwukrotnie pełnił urząd starosty małopolskiego (Urzędnicy małopolscy 1990, s. 285). Był jednym z najzagorzalszych wrogów Władysława Łokietka oraz arcybiskupa Jakuba Świnki. W opinii historyków cechował się wieloma atutami dyplomatycznymi, gospodarczymi oraz strategicznymi, którym zawdzięczał swoją pozycję na dworze praskim. Wacław II powierzył mu nie tylko misje dyplomatyczne, ale również obronę Małopolski przed wrogami zewnętrznymi. $Z$ zadań tych wywiązywał się znakomicie aż do 1306 roku (Pietras 2001b, s. 225-231). Przyczyn jego sukcesów upatrywać należy nie tylko w silnych zbrojnych oddziałach i sprawnym systemie administracyjnym, ale przede wszystkim w licznych zamkach obronnych rozmieszczonych na sporej części ziemi krakowskiej, które skutecznie odpierały ataki i umożliwiały wyprowadzenie kontrakcji. Warownie te zresztą pełniły nie tylko funkcje militarne, stanowiły jednocześnie centra administracyjne, siedziby urzędników i biskupa oraz zapewniały ochronę szlakom handlowym.

Problematyka budownictwa obronnego Jana Muskaty nie doczekała się jeszcze wyczerpującego opracowania pomimo, że wielokrotnie zwracano uwagę 
na jego liczne fundacje zamkowe i konieczność prezentacji zagadnienia. Kwestia ta poruszana była dotychczas głównie przy okazji działalności fundacyjnej biskupów krakowskich lub początków zamków w Małopolsce (Kołodziejski 1995, s. $138-145$; 1997 s. 19-20; 1998, s. 15-17; 2016, s. 811-824; 2017, s. 59-62; Kajzer 2002, s. 293-294). Opracowania te w połączeniu z publikacjami dotyczącymi pojedynczych obiektów, które powiązać można z działalnością wspomnianego biskupa, stanowią podstawowy zasób wiedzy niezbędny do zaprezentowania całości zagadnienia. Nieocenioną w tym pomocą są także prace historyków, szczególnie wspomniana monografia T. Pietrasa (2001b, s. 43 i nn.), w której zgromadzono podstawową bazę źródłoznawczą. Celem artykułu będzie zatem zaprezentowanie i podsumowanie wiedzy na temat obiektów obronnych Jana Muskaty w ziemi krakowskiej. Z uwagi na ograniczoną objętość tekstu, z rozważań wyłączona została druga część Małopolski - ziemia sandomierska. Niniejszy tekst nie wyczerpuje wspomnianego zagadnienia, lukę w badaniach wypełni przygotowywana przez autora rozprawa doktorska, w której zostanie ono rozwinięte.

Punktem wyjścia rozważań na temat działalności budowlanej Jana Muskaty na obszarze ziemi krakowskiej jest rok 1294. Wówczas przyjął on sakrę biskupią i zyskał realną możliwość prowadzenia inwestycji. W jego posiadaniu znalazły się także założenia obronne wzniesione przez poprzedników, chociażby gródek w Muszynie lub - łączony z Pawłem z Przemankowa - zamek w Sławkowie. W przypadku badań nad warowniami Jana Muskaty niezwykle ważny jest również wydany przez Wacława II 20 czerwca 1295 roku w Pradze przywilej zezwalający na umocnienie blancis et fossato munire biskupich miast Kielc, Iłży, Sławkowa i Tarczka (KDKK, nr 101). Dokument ten był wyraźnym zezwoleniem na rozbudowę fortyfikacji i mimo, że dotyczył umocnień miejskich, w dodatku drewnianych, nie można wykluczyć, że Jan Muskata wykorzystywał go także do wznoszenia zamków, chociażby jak w opisywanym niżej Sławkowie. Wacław II mógł również przymykać oko na poczynania biskupa, nie tylko z powodu odległości jaka dzieliła Pragę od Krakowa, ale przede wszystkim ze względu na zaufanie, jakim darzył duchownego. Władca czeski zdawał sobie również sprawę, że zamki wzniesione przez Muskatę, w razie ataku nieprzyjaciela uzupełniać będą warownie królewskie. Zresztą budowanie zamków przez biskupów było w Czechach sytuacją normalną i dopuszczalną, czego przykład stanowi postępowanie biskupa ołomunieckiego - Brunona, który przez kolonizację i rozbudowę umocnień wzmacniał pogranicze morawsko-śląskie (Barciak 1992, s. 57-58; por. też: Kowalewski 2009, s. 10-16 - tam starsza literatura).

Najważniejszą warownią biskupów krakowskich na przełomie XIII i XIV stulecia był zamek w Sławkowie, stanowiący centrum administracyjne ważnego klucza majątkowego, z którego pobierano znaczne dochody pochodzące z pobliskich kopalni i handlu. Ruiny położone są w południowo-wschodniej części miasta, na wyniesieniu opadającym w stronę Białej Przemszy. Geneza tego założenia nie została jeszcze dostatecznie wyjaśniona, jednak badający ten obiekt 
w latach 80. i 90. XX wieku Jacek Pierzak przypuszcza, że warownię wzniósł biskup Paweł z Przemankowa w latach 80. XIII stulecia (Pierzak 1993, s. 228-229; 1999, s. 175-176; Kajzer, Kołodziejski, Salm 2010, s. 459). Pierwotne miało to być rozległe założenie zbliżone do nieregularnego czworoboku o wymiarach $90 \times 75 \times 90 \times 124 \mathrm{~m}$ i powierzchni prawie $9000 \mathrm{~m}^{2}$. Mur obwodowy wyposażony był dodatkowo w obronne baszty otwarte do wewnątrz i ulokowane w murach wschodnim i południowo-wschodnim. Budowę nagle przerwano, zaś następnym etapem w dziejach warowni miało być powstanie wieży mieszkalno-obronnej na rzucie zbliżonym do kwadratu o wymiarach $11 \times 12 \mathrm{~m}$. Powstała ona w wyniku przebudowy jednej z baszt kurtyny południowo-wschodniej. Stara fosa zamkowa została zasypana, a wieżę otoczono nową o szerokości $7 \mathrm{~m}$. Przerwanie budowy wielkiego zamku J. Pierzak wiąże z uwięzieniem Pawła z Przemankowa, w wyniku konfliktu z księciem krakowskim Leszkiem Czarnym. Po uwolnieniu biskup - z uwagi na problemy finansowe - nie mógł kontynuować budowy całego zamku, stąd ograniczył się tylko do wieży mieszkalno-obronnej. Kolejnym etapem przemian obiektu w Sławkowie było dobudowanie do wieży od strony północnej niewielkiego aneksu z klatką schodową, a od strony północno-zachodniej murowanej wieży bramnej. Jednocześnie poszerzono fosę do $10 \mathrm{~m}$, a uzyskaną ziemię przeznaczono na podwyższenie wzgórza zamkowego. Całość zapewne otoczona była drewnianym parkanem. Etap ten J. Pierzak wiąże z działalnością biskupa Jana Muskaty, który do rozbudowy założenia przystąpił na początku XIV stulecia (Pierzak 1993, s. 212-235; 1999, s. 175-181; 2001, s. 61-72). Tezy zaproponowane przez badacza zostały jednak poddane krytyce przez Stanisława Kołodziejskiego (1999, s. 185-192), a i dzisiaj budzą sporo kontrowersji. Wątpliwości można mieć przede wszystkim do tak zwanego zamku wielkiego, w którym J. Pierzak i L. Kajzer widzą warownię typu kasztelowego, będącą pierwszym takim założeniem na ziemiach polskich, zaszczepionym z Królestwa Czeskiego (Kajzer 2000, s. 649; Pierzak 2001, s. 74-75)1. Teza ta wymaga jednak poparcia gruntownymi badaniami archeologicznymi. Przede wszystkim należy rozpoznać zabudowę wewnętrzną zamku, która nadal pozostaje nieznana. Rekonstrukcja tak dużego założenia również może budzić kontrowersje, opiera się bowiem na niewielkiej liczbie odkrytych murów, których pozostały ciąg odtwarzany jest na podstawie konfiguracji terenu. Posiadając tak znaczne rozmiary i wynikającą $\mathrm{z}$ nich powierzchnię (około $9000 \mathrm{~m}^{2}$ ) byłby to jeden z największych zamków na ziemiach polskich, a nawet w środkowej Europie. Stanisław Kołodziejski w swoich uwagach polemicznych stwierdził również, że wskazanie konkretnego fundatora zamku jest jeszcze niemożliwe (Kołodziejski 1999, s. 192). Z całą pewnością zbudowali go w końcu XIII wieku biskupi krakowscy. Wydaje się, że kwestię ewentualnego donatora, jak i genezy warowni, która w tak krótkim czasie przeszła wiele zasadniczych zmian, wskazać mogą tylko kolejne, szeroko zakrojone badania archeologiczne.

\footnotetext{
${ }^{1}$ Na temat założeń tego typu - por. Durdík 1994.
} 
Wracając do Jana Muskaty, jest bardzo prawdopodobne, że prowadził on jakieś prace w Sławkowie, korzystając z przywileju z 1295 roku. Być może - jak sądzi J. Pierzak - biskupowi temu przypisać należy rozbudowę wieży mieszkalnej (Pierzak 1993, s. 229). Prawdopodobne jest, że był on także jej fundatorem od samego początku. Kwestia ta jednak nadal pozostaje otwarta.

Wczesną genezę ma również założenie biskupów krakowskich w Muszynie. Nie chodzi jednak o pozostałości kamiennego zamku, który według najnowszych badań Artura Gintera zbudowano dopiero w XV wieku (Ginter 2014, s. 25-29; por. też Chudzińska 2014, s. 159-182), ale o oddalony o około 100 m na północ obiekt zlokalizowany na wyniesieniu Koziejówka. Niestety, zarówno datowanie jak i rozplanowanie gródka są słabo poznane. Badany był przez Marię Cabalską i Andrzeja Żakiego w 2. połowie XX wieku, wyniki tych eksploracji nie zostały jednak dostatecznie opracowane (Fraś 1966, s. 449-454; Cabalska 1982, s. 275-289; 1987, s. 5-15). Pierwsza badaczka datowała obiekt na okres od XI do XV wieku i nie wykluczała, że na początku XIV stulecia Jan Muskata wzniósł tutaj wieżę obronną, otoczoną drewniano-ziemnym wałem i fosą (Cabalska 1982, s. 280-289). Dokładniejsze ustalenia przyjął A. Żaki, badający warownię w 1963 roku; na podstawie znalezisk datował zamek i gródek na przełom XIII i XIV stulecia z tym, że drewniano-ziemny obiekt spełniał rolę pomocniczą w stosunku do kamiennego założenia (Fraś 1966, s. 450-454). Ostatnio jednak Kazimierz Przyboś - przeprowadzając analizę przekazów pisanych - stwierdził, że początkowo w Muszynie istniało tylko jedno założenie obronne - drewniano-ziemny gródek, przekazany przez scholastyka Wysza z rodu Półkoziców, biskupowi Pawłowi z Przemankowa w 1288 roku (Przyboś 1996, s. 12-13). Następnie warowania została rozbudowana z inicjatywy Muskaty, stając się bazą wypadową dla jego wojsk. W wyniku walk między oddziałami hierarchy a Władysława Łokietka gródek został odebrany biskupom krakowskim i wszedł w obręb domeny monarszej. Kwestię genezy drewniano-ziemnego gródka oraz jego powiązań z biskupem Muskatą wyjaśnić powinny ponowne badania archeologiczne, w które włączone muszą być także metody nieinwazyjne. Będą one pomocne przy ustaleniu przebiegu wałów oraz ewentualnej zabudowy wewnętrznej. Niezbędna jest również ponowna analiza materiałów, a także zachowanej dokumentacji z badań A. Żakiego i M. Cabalskiej.

Analiza przekazów pisanych okazała się pomocna w identyfikacji wymienionego w aktach procesowych Jana Muskaty pod rokiem 1306 castrum Premilovicz, obecnie łączonym z zamkiem Olsztyn koło Częstochowy (MPV, nr 121). Pierwszym, który powiązał go z ruinami monumentalnego założenia w Olsztynie był Zygmunt Holcer (1970, s. 311-313), do takich samych wniosków doszedł także krakowski badacz Jacek Laberschek (1995, s. 21-22). Castrum Premilovicz z Olsztynem wiążą również S. Kołodziejski i L. Kajzer, którzy za pierwotny człon zamku uznają tak zwaną Wieżę Sołtysią, położoną na wyniosłym ostańcu skalnym, w odległości 200 m na południowy zachód od właściwego założenia. Obaj badacze skłonni są łączyć ten element z działalnością Jana Muskaty 
(Kołodziejski 1998, s. 16; Kajzer 2002, s. 293-294). Warto również nadmienić, że badający wspomniany zamek w ubiegłym stuleciu Włodzimierz Błaszczyk odkrył tam ślady osadnictwa z 2. połowy XIII stulecia, w tym srebrny grosz praski Wacława II, znaleziony w wykopie przy drugiej bramie (Błaszczyk 1961, s. 71-76). Odkrycie to wzmacnia hipotezę, że genezy zamku należy doszukiwać się w działalności stronników króla czeskiego. Dokładne datowanie i fundatora założenia powinny wyjaśnić badania archeologiczne, obejmujące nie tylko zamek górny i średni, ale przede wszystkim obręb Wieży Sołtysiej.

Z obszaru ziemi krakowskiej z działalnością Jana Muskaty wiązać trzeba jeszcze zamek Lipowiec, położony w miejscowości Babice. Zakonserwowane w postaci trwałej ruiny pozostałości warowni wznoszą się na wzgórzu usy tuowanym na północ od niej. W świetle przekazów pisanych właścicielami wsi Lipowa, utożsamianej z Lipowcem, byli Gryfici, a następnie Klemens z Ruszczy. Wojewoda krakowski w 1. połowie XIII wieku przekazał ją benedyktynkom ze Staniątek. Wówczas na jednym ze wzgórz nad wsią jacyś rozbójnicy zbudowali zamek, z którego napadali na pobliskie tereny. W efekcie ataku wojsk książęcych został on zdobyty i przekazany przez władcę biskupowi krakowskiemu Prandocie, który na miejscu rozbójniczego gniazda wzniósł nową warownię (Jan Długosz 1864, s. 297-298; por. też Zagórowski 1960, s. 179-181). Niestety, liczne akcje badawcze nie doprowadziły do potwierdzenia informacji z przekazów pisanych i wyjaśnienia genezy założenia. Obecnie za najstarszy element uważa się cylindryczną wieżę obronną o średnicy $9 \mathrm{~m}$, której budowa miała miejsce w końcu XIII stulecia $\mathrm{z}$ inicjatywy Jana Muskaty, jeszcze w obrębie umocnień drewniano-ziemnych (Małkowska-Holcerowa 1989, s. 6-8; Kajzer, Kołodziejski, Salm 2010, s. 78-79). Potwierdzeniem tego mogą być również źródła pisane, w których wymieniony jest zamek. W aktach procesowych Jana Muskaty pod rokiem 1308 roku widnieje bowiem zapiska, że z warowni wyprawiały się jego najemne oddziały dowodzone przez Gerlacha de Culpen, zaś pięć lat wcześniej biskup osobiście wystawił w nim dokument, w którym zezwolił osadzić na prawie niemieckim wieś Jeleń nad rzeką Białą Przemszą (MPV, nr 121; Zbiór dokumentów, nr 14). Ostatnio jednak Jerzy Rajman zakwestionował takie datowanie, twierdząc, że pierwotna warowania wraz $\mathrm{z}$ dolną partią wieży wzniesiona została $\mathrm{w}$ czasie urzędowania na stolcu biskupim Prandoty w latach 1242-1266 (Rajman 2014, s. 90-93). Kwestię początku założenia powinny wyjaśnić systematyczne prace archeologiczne.

Wieża cylindryczna zamku w Lipowcu posiada liczne analogie z terenu Polski i Czech. W tym samym okresie powstały bowiem podobne elementy obronne na zamkach w Czorsztynie, Czchowie, Rytrze, Dobczycach oraz Kazimierzu Dolnym, które wiąże się z działalnością budowlaną Wacława II, od którego Muskata czerpał wzorce (Kołodziejski 2011, s. 315-328; Mitrus 2015, s. 82). Analogią może być także wieża zamku biskupów krakowskich w Iłży, na ziemi sandomierskiej (Kajzer, Kołodziejski, Salm 2010, s. 202-204). Licznych przykładów bergfriedów wznoszonych przez ostatnich Przemyślidów możemy doszukiwać się również 
w Czechach, na przykład: Bezděz, Hasištejn, Jivno, Valdek oraz Vitějovice (Durdík 2001, s. 58-60, 94-95, 125, 300-301, 310-311).

Odrębnym zagadnieniem są czasy pełnienia urzędu starosty małopolskiego przez Jana Muskatę w latach 1304-1305 oraz 1305-1306 (Urzędnicy małopolscy 1990, s. 285). Okres ten został naświetlony w drugim procesie kanonicznym wytyczonym biskupowi w 1308 roku przez arcybiskupa Jakuba Świnkę. Świadkowie zeznali, że dowódcy wojskowi Muskaty - Gerlach de Culpen, Sygard, Fryderyk, Lutko, Otto Malczicz, Spaczman, Rulko, Peszko i Kunczko, dopuszczali się wielu mordów, napadów i okrucieństw (MPV, nr 121; por. także Pietras 2001b, s. 216-220). Dowódcy ci z pewnością posiadali swoje stałe zamki, z których organizowali wypady. O Gerlachu de Culpen, szwagrze biskupa i zarządcy zamku Lipowiec oraz wójcie wielickim, wspomniano już wyżej. Szczegółowa analiza przekazów pisanych pozwoliła na identyfikację kolejnego dowódcy - Peszka z zamkiem Skała w Sułoszowej, który od jego imienia przyjął nazwę Peskensten (Laberschek 2000a, s. 144-147). Obiekt ten, o lokalizacji od dawna budzącej w literaturze wiele wątpliwości, został zidentyfikowany w czasie badań S. Kołodziejskiego w 1993 roku na wzgórzu Kocica w Sułoszowej (Kołodziejski 1996, s. 101-110). Zamek powstał z inicjatywy Henryka Brodatego w 1. połowie XIII stulecia, następnie pozostawał w rękach zarządców książąt krakowskich. W 1291 roku jeden z takich burgrabiów - Henryk z Woszowa, oddał go Wacławowi II (Regesta diplomatica, $\mathrm{nr} 1531$ ); pod zarządem starostów małopolskich warownia przetrwała do początku XIV stulecia.

Niestety, z uwagi na brak źródeł pisanych pozostałym dowódcom nie można przyporządkować zamków. Wydaje się jednak bardzo możliwe, że zasiadali oni w licznie odnotowanych przez archeologów na obszarze Jury Krakowsko-Częstochowskiej założeniach obronnych, datowanych na schyłek XIII i początek XIV stulecia. Zaliczyć do nich można zamek Ostrężnik (Kołodziejski 2004, s. 19-24; por. też Laberschek 2006, s. 198-199), badane przez Błażeja Muzolfa obiekty w Grodzisku Pańskim, Birowie oraz Biśniku (Muzolf 1996, s. 109-112; 1998a, s. 18-20; 1998b, s. 114-117), a także odkryte przez Michała Wojenkę grodzisko w Jerzmanowicach (Wojenka 2016, s. 663-673). Do grupy tych obiektów włączyć można wymienione w aktach procesowych, zajęte przez zbrojne załogi klasztor w Tyńcu oraz grodzisko w Piekarach (MPV, nr 121).

Wszystkie powyższe obiekty warowne powstały zapewne na początku XIV stulecia, a więc w okresie upadku rządów czeskich. Wznoszone były szybkim i tanim kosztem, ulokowane zaś w naturalnie ufortyfikowanym i trudno dostępnym terenie. Służyły jako bazy wypadowe dla wojsk czeskich, umożliwiały ponadto utrzymanie podbitych lub zagrożonych niepokojami wewnętrznymi terenów. Jednocześnie mogły spowolnić marsz wrogich armii. Biorąc pod uwagę powyższe funkcje Jacek Laberschek określił je mianem gniazd (zamków) rozbójniczych (Laberschek 2000b, s. 172). Termin ten w gruncie rzeczy wydaje się słuszny, gdyż takie były ich podstawowe zadania. Warto jednak wziąć pod uwagę 
także inne możliwe funkcje. Być może przez ich budowę Jan Muskata chciał powiększyć obszary domeny monarszej, stanowiącej na tym terenie mniejszość w stosunku do posiadłości rycerskich oraz kościelnych ${ }^{2}$. Proces ten byłby jednym z etapów rewindykacji dóbr monarszych, której początku doszukiwać się można w czasach panowania Wacława II, kontynuowanej następnie przez Władysława Łokietka i Kazimierza Wielkiego (Kurtyka 2001, s. 143-147; Laberschek 2008, s. 461-462). Budowanie zamków i innych warowni, będących jednocześnie siedzibami urzędników lub administratorów dóbr sprzyjało rozwojowi kolonizacji i osadnictwa. Zapewne to także było celem tych obiektów, przynajmniej w dłuższej perspektywie czasowej.

Z typem zamku rozbójniczego powiązać również trzeba zamek Kurów położony nad Dunajcem na Sądecczyźnie, z którego obecnie pozostały już tylko nikłe formy terenowe w postaci fos i wałów. Obiekt odkryty i badany był przez A. Żakiego w latach 60 . XX wieku, który na podstawie pozyskanych zabytków datował go na przełom XIII i XIV wieku (Żaki 1964, s. 41-46). Wyniki badań archeologicznych uzupełniła kwerenda historyczna Kazimierza Dziwika (1971, s. 79-89), który powiązał odkryte relikty z wymienionym w źródłach z 1308 roku castrum Curow (MPV, nr 121). Była to niewielka warownia, zapewne drewniano-ziemna (aczkolwiek z uwagi na zły stan badań nie można wykluczyć jakichś lekkich konstrukcji murowanych), zbudowana w celu kontroli pobliskich terenów w okresie po 1304 roku i niedługo później zniszczona lub opuszczona.

Spodziewać się można, że w najbliższej przyszłości liczba podobnych założeń zwiększy się dzięki badaniom archeologicznym wykorzystującym nowoczesne metody nieinwazyjne (np. LiDAR). Konieczna wydaje się również weryfikacja rezultatów starszych badań, gdyż ich wyniki nie zawsze były dobrze opracowane lub zinterpretowane. Problematyka tak zwanych zamków rozbójniczych nadal pozostaje kwestią wymagającą szczegółowych studiów.

Na zakończenie warto kilka słów poświecić zamkowi w Bieczu, wzniesionym na przełomie XIII i XIV wieku na wzgórzu położonym na zachód od miasta, w miejscu starego grodu kasztelańskiego. Na mocy układu z 1292 roku został on przekazany w 1303 roku Janowi Muskacie, ten zaś oddał zarząd nad zamkiem opatowi tynieckiemu - Michałowi (Jan Dlugosz 2009, s. 25-26). Opat nie mogąc utrzymać warowni, utracił ją na rzecz Węgrów i Władysława Łokietka. Około 1304 roku siły Wacława II odbiły zamek, jednak nie zwróciły go już biskupowi krakowskiemu (Kaleta 1963, s. 82-115).

Na przykładzie zarysowanych powyżej 14 zamków wyraźnie widać, że działalność fundacyjna w dziedzinie budownictwa warownego Jana Muskaty była ogromna. Nie chodzi tutaj wyłącznie o liczbę, ale również jakość i charakter wznoszonych budowli. Założenia te swoim rozmachem (Lipowiec, Przymiłowice, Sławków) dorównywały fundacjom książąt piastowskich, a nawet potężnemu

\footnotetext{
${ }^{2} \mathrm{Na}$ temat osadnictwa w tym regionie - por. Kiryk 1978, s. 49-60; Rajman 1998, s. 82-125; Laberschek 2016, s. 77-93.
} 
Wacławowi II, od którego Muskata czerpał wzorce płynące bezpośrednio z Królestwa Czech. Zresztą działalność budowalną biskupa krakowskiego rozpatrywać należy wyłącznie w kontekście panowania Wacława II i jego fundacji obronnych, są one bowiem ze sobą ściśle powiązane. Wynika to nie tylko ze stosunków między obiema postaciami, ale również $\mathrm{z}$ ich zbieżnych interesów.

Możliwość budowy nowych zamków, jak i rozbudowy starszych założeń zawdzięczał Jan Muskata nie tylko przychylności i wsparciu Wacława II. Zasiadając w 1294 roku na stolcu biskupim obejmował zwierzchnictwo nad największą polską diecezją pod względem powierzchni i drugą pod względem liczby ludności. Tereny biskupstwa krakowskiego były także bardzo dobrze rozwinięte pod kątem gospodarczym i urbanistycznym. Biskup czerpał dochody nie tylko z licznych uposażeń, ale również z handlu, żup krakowskich i kopalni kruszcowych, chociażby z okolic Sławkowa. Wszystko to powodowało, że biskupi krakowscy należeli do najbogatszych na ziemiach polskich (Inglot 1925; Szymański 1966, s. 180; Wiśniowski 1988, s. 443). Posiadając tak bogate zaplecze gospodarcze i finansowe oraz dysponując rozległymi uprawnieniami immunitetowymi już w 2. połowie XIII wieku przystąpili oni do budowy pierwszych założeń obronnych (np. Sławków). Proces ten osiągnął apogeum w czasie pontyfikatu Jana Muskaty, który korzystając ze swojej pozycji na dworze praskim oraz mając spore możliwości finansowe umocnił większość starszych założeń, a także wniósł nowe.

W działalności budowlanej Jana Muskaty wyróżnić można dwa wyraźne nurty. Pierwszy powiązany jest z rozbudową starszych założeń i wprowadzaniem pierwszych elementów murowanych, o czym świadczą zamki w Sławkowie, Lipowcu i Przymiłowicach. Znajdowały się one na terenie kościelnych kluczy majątkowych, w dodatku niezwykle dochodowych. Nie dziwi zatem fakt, że Muskata umacniał je, czyniąc silnymi punktami oporu i centrami administracyjnymi swoich włości. O ich skuteczności przekonał się nieraz Władysław Łokietek. Etap ten wiąże się również z zagadnieniem początków murowanych założeń obronnych w Małopolsce, w rozpowszechnieniu których spory udział miał właśnie Muskata, na co wskazywali już S. Kołodziejski i L. Kajzer (Kajzer 2002, s. 294; Kołodziejski 2017 s. 60-62).

Drugi nurt wiąże się z czasami pełnienia urzędu starosty przez biskupa naświetlonymi przez akta procesowe. Wówczas z jego inicjatywy wniesiono liczne niewielkie warownie, które w literaturze nazwano rozbójniczymi. Spełniały one głównie rolę placówek militarnych i baz wojskowych, aczkolwiek ich pozostałe funkcje nie zostały jeszcze poznane. Zapewne większość z nich upadła wkrótce po obaleniu rządów czeskich i stopniowym przejmowaniu zamków przez zwolenników Władysława Łokietka. Zwraca jednak uwagę ich duże zgrupowanie na terenie Jury Krakowsko-Częstochowskiej (ryc. 1). Być może skupisko to wynika ze słabego stanu badań pozostałych obszarów Małopolski, na których nie zawsze przeprowadzono dostateczne inwentaryzacje obiektów militarnych z późnego średniowiecza. Wytłumaczeniem ich liczby na terenie Jury mogą być również 
biegnące tamtędy szlaki handlowe, naturalnie ufortyfikowany teren sprzyjający zakładaniu tego typu założeń lub chęć systematycznego powiększenia domeny monarszej.

Zarysowana w dużym skrócie problematyka badań nad zamkami Jana Muskaty w ziemi krakowskiej stanowi jedynie krótki rys całego zagadnienia, które rozpatrywane powinno być w szerszym kontekście, chociażby z uwzględnieniem ziemi sandomierskiej. Jednak już na tym etapie badań stwierdzić można, że dokonania tego biskupa w dziedzinie budownictwa warownego były ogromne (ryc. 2). Liczne inicjatywy sprzyjały rozpowszechnieniu murowanych założeń obronnych oraz zagęszczeniu sieci warowni w ziemi krakowskiej, co podkreślane jest w literaturze przedmiotu (Pietras 2001b, s. 137; Kajzer 2002, s. 294; Kołodziejski 2017, s. 60). Fundacja tak licznych zamków sprzyjała nie tylko umocnieniu władzy czeskiej i panowania Wacława II, którego stronnikiem był Muskata. Infułat miał w tym również swój prywatny cel, wzorem biskupów wrocławskich dążył do utworzenia niezależnego księstwa biskupiego. Zamierzania takie sugerował już w 1951 roku Edmund Długopolski (2009, s. 123), podkreślane to jest również przez innych badaczy (Gawlas 1996, s. 85; 1997, s. 393-401; Maciejowski 2007, s. 233-235; Pietras 2001b, s. 137). Problematyki tej nie opracowano jednak dostatecznie, warto zatem poświęcić jej nieco uwagi. Zdaniem autora, trzonem księstwa miały być zachodnie części Małopolski, a więc bogate klucze biskupie skupione wokół Lipowca, Przymiłowic i Sławkowa. Na ich terenie znajdowały się liczne kopalnie ołowiu i srebra oraz przebiegały ważne szlaki handlowe - z Wrocławia do Krakowa i z południa na północ (Wyrozumska 1977, s. 58-60; Kozłowski 1889, s. 56-83, 421-440). Obszary te dawały mocne podstawy do stworzenia silnego władztwa terytorialnego. Znajdowały się również blisko granic ze Śląskiem i Czechami, skąd sojusznicy Jana Muskaty w nagłych przypadkach mogli ruszyć mu z pomocą zbrojną. Chęć utworzenia własnego księstwa tłumaczą liczne fundacje zamkowe, zarówno w formie silnych warowni kamiennych, stanowiących punkty władzy administracyjnej, jak i rozbójniczych, zapewniających ochronę ziem biskupa od strony wschodniej, skąd mógł nadejść atak Władysława Łokiet$\mathrm{ka}^{3}$. W kontekście tym rozumieć należy również lokacje miast i wsi na prawie niemieckim. Przykładem takich działań było zezwolenie wydane na ręce biskupa w 1297 roku przez Władysława Łokietka, pozwalające na lokację osad w okręgu piątkowiskim (KDKK, nr 102, 103); Stanisław Zajączkowski (1968, s. 20-21) i Tomasz Pietras (2001b, s. 123) dostrzegają w nim zalążek późniejszych Pabianic. Celom politycznym i gospodarczym przyświecały także założenie wsi Jeleń nad Przemszą (Zbiór dokumentów, nr 14) oraz otrzymanie od Mieszka cieszyńskiego miasta Kęty nad Sołą (MPV, nr 121). Potwierdzeniem aktywności Jana Muskaty w zakresie kolonizacji są akta procesowe, w których z zeznań świadków wynika,

${ }^{3} \mathrm{~W}$ dalszej perspektywie zamki rozbójnicze sprzyjałyby powiększaniu się domeny biskupiej, kosztem ziem należących do rycerstwa i w konsekwencji oderwaniu tych ostatnich od Małopolski, przyłączając jednocześnie do terenów biskupiego księstwa Jana Muskaty. 


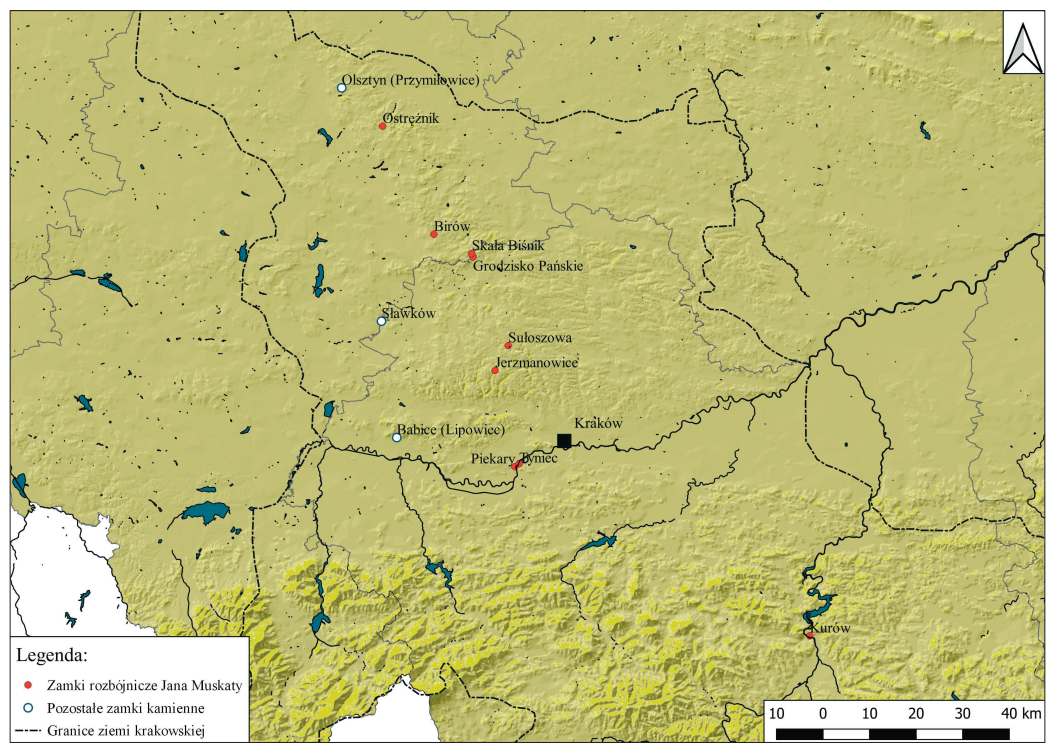

Ryc. 1. Zamki Jana Muskaty w Jurze Krakowsko-Częstochowskiej, z wyszczególnieniem tzw. gniazd rozbójniczych (oprac. P. Kocańda)

Fig. 1. Castles of Jan Muskata in the Kraków-Częstochowa Upland, with specification of the so-called robbers' nests (edited by P. Kocańda)

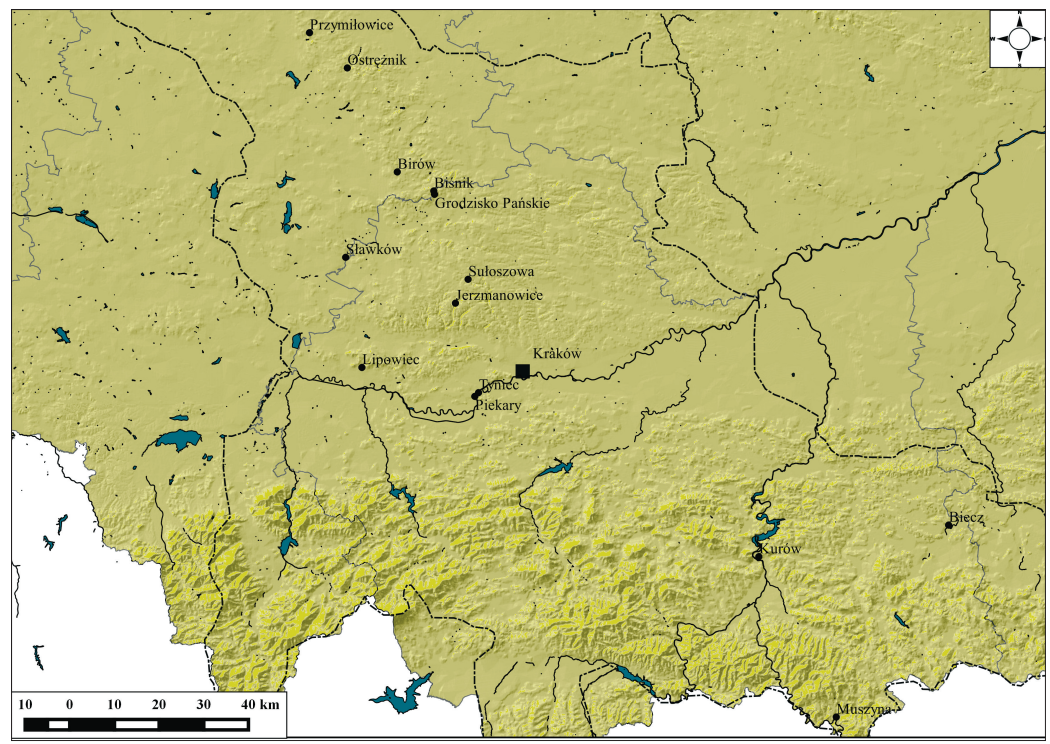

Ryc. 2. Zamki biskupa Jana Muskaty w ziemi krakowskiej (granice terytorialne zaznaczono przerywaną linią) (oprac. P. Kocańda)

Fig. 2. Castles of Bishop Jan Muskata in Krakow Land (territorial boundaries marked with dotted line) (edited by P. Kocańda) 
że zakładał on wsie bez zgody kapituły (MPV, nr 121). Wyrazem sprzyjania królów Czech i Polski w dążeniu do utworzenia samodzielnego władztwa terytorialnego było tytułowanie Jana Muskaty księciem. Określenie takie występuje w kilku dokumentach. W akcie z 1295 roku, zezwalającym na ufortyfikowanie Sławkowa, Iłży, Kielc i Tarczka, Wacław II tytułuje go principis et fidelis (KDKK, nr 101). W 1301 roku Wacław III, panujący na Węgrzech jako Władysław V nazywa biskupa princeps noster (KDKK, nr 105). Wreszcie w akcie przekazania miasta i zamku w Bieczu, w 1303 roku król czeski ponownie określa go księciem (KDKK, nr 111). Biskup Jan Muskata, co podkreśla T. Pietras (2001b, s. 137), uzyskał dla Kościoła krakowskiego liczne i bogate nadania, jednocześnie jego inicjatywy budowlane pochłaniały wielkie kwoty pieniędzy. Koszty te niestety ponosiły dobra biskupie diecezji. Zbytnie zaangażowanie się w politykę było błędem; gdyby nie nagły upadek rządów czeskich w 1306 roku, które swoje długie utrzymanie zawdzięczały działaniom biskupa krakowskiego, zapewne Jan Muskata zrealizowałby swój plan.

\section{Bibliografia}

\section{Źródla}

Jan Dlugosz

KDKK

MPV

Regesta diplomatica

Zbiór dokumentów
- Liber beneficiorum dioecesis Cracoviensis, t. 3, [w:] Opera omnia, t. 9, wyd. A. Przeździecki, Kraków 1864.

Roczniki czyli kroniki sławnego Królestwa Polskiego, ks. 9: 1300-1370, thumacz. J. Mrukówna, Kraków 2009.

- Kodeks dyplomatyczny katedry krakowskiej św. Wacława, cz. 1, wyd. F. Piekosiński, Kraków 1874.

- Monumenta Polonia Vaticana, t. 3: Analecta Vaticana 12021366, wyd. J. Ptaśnik, Kraków 1914.

- Regesta diplomatica nec non epistolaria Bohemiae et Moraviae, wyd. J. Emler, t. 2, Praha 1882.

- Zbiór dokumentów małopolskich, cz. 1, wyd. S. Kuraś, Wrocław 1962.

\section{Literatura}

Wykaz skrótów

$\begin{array}{lll}\text { NP } & - & \text { Nasza Przeszłość, Kraków } \\ \text { RS } & - & \text { Rocznik Sądecki, Nowy Sącz } \\ \text { TK } & - & \text { Teki Krakowskie, Kraków }\end{array}$

Barciak A.

1992 Czechy a ziemie poludniowej Polski w XIII oraz w początkach XIV wieku. 
Polityczno-ideologiczne problemy ekspansji czeskiej na ziemie potudniowej Polski, Katowice.

Błaszczyk W.

1961 Zamek w Olsztynie. Krótki rys historyczny $i$ wyniki wstęnnych badań archeologicznych z roku 1959, Ziemia Częstochowska, t. 4, s. 65-78.

Brzostowska I.

2001 Zamki biskupie i kapitulne na Warmii w kontekście architektury obronnej i rezydencjonalnej, [w:] Zamek i dwór w średniowieczu od XI do XV wieku. Materiały XIX Seminarium Mediewistycznego, red. J. Wiesiołowski, Poznań, s. $53-57$.

Cabalska M.

1982 Zespół osadniczy w Muszynie, woj. Nowy Sącz. Gródek, RS, t. 15, s. 275-289.

1987 Zespół osadniczy w Muszynie, woj. Nowy Sacz. Zamek, RS, t. 18, s. 5-16. Chudzińska B.

2014 Zamek w Muszynie. Stan badań do roku 2010, [w:] Zamki w Karpatach, red. J. Gancarski, Krosno, s. 159-186.

Długopolski E.

2009 Władysław Łokietek na tle swoich czasów, reedycja wydania z 1951 roku, Kraków.

Durdík T.

1994 Kastellburgen des 13. Jahrhunderts in Mitteleuropa, Wien-Köln-Weimar.

2001 Encyklopedie českých hradì, Praha.

Dziwik K.

1971 Gródek biskupa Jana Muskaty w Kurowie nad Dunajcem, RS, t. 12, s. 79-89.

Fraś M.

1966 Wstepne badania archeologiczne na zamku w Muszynie, RS, t. 7, s. 449-454.

Gawlas S.

1996 O ksztalt zjednoczonego Królestwa. Niemieckie władztwo terytorialne a geneza spoleczno-ustrojowej odrębności Polski, Warszawa.

1997 Człowiek uwikłany w wielkie procesy-przykład Muskaty, [w:] Człowiek w społeczeństwie średniowiecznym, red. R. Michałowski, Warszawa, s. 391-401.

Ginter A.

2014 Zamek $w$ Muszynie $w$ świetle najnowszych badań archeologiczno-architektonicznych, Almanach Muszyny, s. 5-29.

Holcer Z.

1970 Dwie lustracje zamku w Olsztynie koło Czestochowy, Sprawozdania z posiedzeń komisji naukowych PAN, t. 13, z. 1, s. 311-313.

Inglot $\mathrm{S}$.

1925 Stan i rozmieszczenie uposażenia biskupstwa krakowskiego w połowie $X V$ wieku, Lwów.

Kajzer L.

1983 Uwagi o budownictwie obronnym arcybiskupów gnieźnieńskich, Acta Universitatis Lodziensis. Folia Archaeologica 3, s. 147-158. 
1990 Zamek w Raciążku, Łódź.

1994 Z problematyki budownictwa obronnego biskupów włocławskich, NP, t. 82, s. 281-298.

1997 Z problematyki badań zamków biskupów w Polsce średniowiecznej, [w:] Siedziby biskupów krakowskich na terenie dawnego województwa sandomierskiego, red. L. Kajzer, Kielce, s. 7-14.

2000 Czyw średniowiecznej Polsce wznoszono zamki kasztelowe, [w:] Archeologia w teorii $i$ w praktyce, red. A. Buko, P. Urbańczyk, Warszawa, s. 639-649.

$2002 \quad Z$ badań nad zamkami w Polsce $w$ wieku XIII, Kwartalnik Historii Kultury Materialnej, R. 50, nr 3-4, s. 287-304.

Kajzer L., Kołodziejski S., Salm J.

2010 Leksykon zamków w Polsce, Warszawa.

Kaleta R.

1963 Zamek w Bieczu, [w:] Biecz. Studia historyczne, red. R. Kaleta, Wrocław, s. $82-115$.

Kiryk F.

1978 Zarys dziejów osadnictwa, [w:] Dzieje Olkusza i regionu olkuskiego, t. 1, red. F. Kiryk, R. Kołodziejczyk, Warszawa-Kraków, s. 41-141.

Kocańda P.

2016 Kariera biskupa krakowskiego Jana Muskaty u boku króla Wacława II, [w:] Obrazy przeszłości. Studia z zakresu historii, literatury i kultury, t. 2, red. R. Majzner, K. Całus, Częstochowskie Teki Filologiczno-Historyczne, Częstochowa, s. 185-196.

Kołodziejski S.

1986 Początki średniowiecznych rezydencji obronnych możnowładztwa w Małopolsce, Sprawozdania z posiedzeń komisji naukowych PAN, t. 27, z. 1, s. 16-18.

1992 Wstęp do studiów nad geneza obronnych rezydencji możnowładztwa, [w:] Stan i potrzeby badań nad wczesnym średniowieczem $w$ Polsce, red. Z. Kurnatowska, Poznań-Wrocław-Warszawa, s. 275-282.

1994 Regale grodowe w świetle nowych badań, Sprawozdania z posiedzeń komisji naukowych PAN, t. 36, z. 1-2, s. 171-172.

1995 Uwagi o średniowiecznym budownictwie obronnym biskupów krakowskich, TK, t. 3, s. 135-149.

1996 Castrum Scala-zamek księcia ślaskiego Henryka Brodatego pod Krakowem, [w:] Kultura średniowiecznego Śląska i Czech. Zamek, red. K. Wachowski, Wrocław, s. 101-111.

1997 Obronne siedziby biskupów krakowskich. Zarys problematyki badawczej, [w:] Siedziby biskupów krakowskich na terenie dawnego województwa sandomierskiego, red. L. Kajzer, Kielce, s. 17-22.

1998 Początki zamków na Wyżynie Krakowsko-Częstochowskiej, TK, t. 7, s. 13-23.

1999 Zamek stawkowski - wątpliwości ciag dalszy, TK, t. 10, s. 185-193.

2004 Zamek Ostrężnik ws świetle dotychczasowych badań, [w:] Zróżnicowanie i przemiany środowiska przyrodniczo-kulturowego Wyżyny Krakowsko-Częstochowskiej, t. 2, red. J. Partyka, Ojców, s. 19-24. 
2011 Król Wacław II - budowniczy zamków na pograniczu polsko-węgierskim, [w:] II Forum Architectura Medievalis, red. K. Stala, Kraków, s. 315-328.

2016 Średniowieczne zamki biskupów krakowskich, [w:] Działalność fundacyjna biskupów krakowskich, t. 1, red. M. Walczak, Kraków, s. 807-825.

2017 Poczatki zamków w ziemi krakowskiej [w:] Początki murowanych zamków w Polsce do połowy XIV w., red. A. Bocheńska, P. Mrozowski, Warszawa, s. $47-66$.

Kowalewski K.

2009 Rycerze, włodycy, panosze. Ludzie systemu lennego w średniowiecznych Czechach, Warszawa.

Kozłowska-Budkowa Z.

1976 Przyczynki do życiorysu Jana Muskaty, [w:] Ars historica. Prace z dziejów powszechnych i Polski, red. M. Biskup, Poznań, s. 445-453.

Kozłowski K.

1889 Kopalnie klucza sławkowskiego (ustęp do dzieła poświęconego poszukiwaniom na polu historyi przemysty górniczego w dawnej Polsce), Biblioteka Warszawska, t. 2(190), s. 56-83, 421-440.

Kurtyka J.

2001 Odrodzone Królestwo. Monarchia Władysława Łokietka i Kazimierza Wielkiego w świetle nowszych badań, Kraków.

Laberschek J.

1995 Nieznane karty z przeszłości zamku Olsztyn i starostwa olsztyńskiego (wiek XIII-XV), Almanach Częstochowy 1994, s. 19-30.

2000a Tajemnicze ,castrum Pesconis”. Próba rozwikłania zagadki rozbójniczego zamku małopolskiego z początku XIV stulecia, [w:] Krajobrazy. Księga pamiątkowa w 70. rocznice urodzin profesora Janusza Bogdanowskiego, red. S. Kołodziejski, J. Marcinek, R. Marcinek, Kraków, s. 143-147.

2000b Czy istnial w średniowieczu system obronny na Jurze, TK, t. 12, s. 167-179.

2006 Na tropie rycerzy z Potoku i rozbójników z Ostręznika, [w:] Częstochowa i jej okolice w średniowieczu, red. J. Laberschek, Kraków, s. 177-199.

2008 Bezpośrednie zaplecze gospodarcze zamków województwa krakowskiego do połowy XVI wieku, [w:] Historia vero testis temporum. Ksiega jubileuszowa poświęcona Profesorowi Krzysztofowi Baczkowskiemu w 70. rocznicę urodzin, red. J. Smołucha, A. Waśko, T. Graff, Kraków, s. 459-476.

2016 Ojców i okolice do połowy XVI wieku, [w:] Monografia Ojcowskiego Parku Narodowego. Dziedzictwo kulturowe, red. J. Partyka, Ojców, s. 75-105.

Lasek L.

2013 Turris fortissima nomen Domini. Murowane wieże mieszkalne w Królestwie Maciejowski M. Polskim od 1300 r. do połowy XVI w., Warszawa.

2003 Ostatnie lata biskupa krakowskiego Jana Muskaty (1317-1320), [w:] Biskupi, lennicy, żeglarze, Gdańskie studia z dziejów średniowiecza, t. 9, red. B. Śliwiński, Gdańsk, s. 93-11. 
2007 Orientacje polityczne biskupów metropolii gnieźnieńskiej 1283-1320, Kraków. Małkowska-Holcerowa T.

1989 Lipowiec dawny zamek biskupów krakowskich, Warszawa.

Marciniak-Kajzer A.

1996 Dwory biskupów krakowskich w XVw. Przyczynek do rekonstrukcji zaginionej czéści Liber beneficiorum Jana Dlugosza, Acta Universitatis Lodziensis. Folia Archaeologica 20, s. 97-110.

Mitrus E.

2015 Zespół zamkowy w Kazimierzu Dolnym, badania archeologiczne w latach 2010-2013, [w:] Zamki Lubelszczyzny w źródtach archeologicznych, red. E. Banasiewicz-Szykuła, Lublin, s. 71-98.

Modzelewski K.

1980 Między prawem ksiązęcym a władztwem gruntowym. II. Instytucja kasztelanii majątkowych kościoła w Polsce XII-XIII w., Przegląd Historyczny, t. 71, z. 1,

Muzolf B. s. 449-477.

1996 Badania na skale z Jaskinia Biśnik i na górze Grodzisko Pańskie w Strzegowej, woj. Katowice, Łódzkie Sprawozdania Archeologiczne, t. 2, s. 109-127.

1998a Badania na skale Grodzisko Pańskie w Strzegowej, województwo katowickie, Badania archeologiczne na Górnym Śląsku i ziemiach pogranicznych w 1995 roku, s. 18-20.

1998b Badania na Górze Birów w Podzamczu, województwo katowickie, Badania archeologiczne na Górnym Śląsku i ziemiach pogranicznych w 1995 roku, s. $114-117$.

Nowakowski T.

1991 Polityka biskupów krakowskich w końcu XIII wieku (Prokop i Jan Muskata), NP, t. 75, s. 5-27.

Pierzak J.

1993 Zamek biskupów krakowskich w Stawkowie, woj. katowickie-jedno z najstarszych murowanych założen obronnych $w$ Polsce południowej, Sprawozdania Archeologiczne, t. 45, s. 213-238.

1999 Kilka uwag na temat zamku biskupów krakowskich w Stawkowie, TK, t. 10, s. 175-184.

2001 Najdawniejsze dzieje, [w:] Dzieje Stawkowa, red. F. Kiryk, Kraków, s. 51-78.

Pietras T.

2001a W kwestii pochodzenia biskupa krakowskiego Jana Muskaty, Acta Universitatis Lodziensis. Folia Historica 72, s. 5-25.

2001b „Krwawy wilk z pastorałem”. Biskup krakowski Jan zwany Muskata, Warszawa.

Pietrzak J.

2000 Prywatne zamki biskupów polskich w pierwszej połowie XV wieku, [w:] Oporów. Stan badań. Materiały z sesji naukowej zorganizowanej z okazji 50. Rocznicy Muzeum w Oporowie 22 listopada 1999 roku, red. G. Kin-Rzymkowska, U. Kowalska, A. Majewska-Rau, Oporów, s. 107-134. 
Proksa M.

1994 Małe założenia obronno-rezydencjonalne fundacji biskupów przemyskich w ziemi przemyskiej i sanockiej, Materiały i Sprawozdania Rzeszowskiego Ośrodka Archeologicznego za rok 1993, s. 294-299.

Przyboś K.

1996 Zamek w Muszynie, Almanach Muszyny 1996, s. 12-16.

Rajman J.

1998 Pogranicze śląsko-małopolskie wśredniowieczu, Kraków.

2014 Lipowiec. Z dziejów zamku i klucza majątkowego biskupów krakowskich (XIII-XVI w.), [w:] Scientia nihil est quam veritatis imago. Studia ofiarowane Profesorowi Ryszardowi Szczygłowi w siedemdziesięciolecie urodzin, red. A. Sochacka, P. Jusiak, Lublin, s. 89-99.

Rodziewicz A.

1995 O dacie elekcji Jana Muskaty na biskupstwo krakowskie, [w:] Polska, Prusy, Ruś. Rozprawy ofiarowane prof. zw. dr hab. J. Powierskiemu w 30-lecie pracy naukowej, red. B. Śliwiński, Gdańsk, s. 129-136.

Siedziby biskupów krakowskich

1997 Siedziby biskupów krakowskich na terenie dawnego województwa sandomierskiego, red. L. Kajzer, Kielce.

Szymański J.

1966 Biskupstwa polskie w wiekach średnich. Organizacja i funkcje, [w:] Kościót w Polsce. Studia nad historia kościoła katolickiego w Polsce, red. J. Kłoczowski, Kraków, s. 127-233.

Urzędnicy matopolscy

1990 Urzędnicy małopolscy XII-XIV wieku. Spisy, oprac. J. Kurtyka i in., [w:] Urzędnicy dawnej Rzeczypospolitej XII-XVIII wieku. Spisy, red. A. Gąsiorowski, t. 4 , z. 1, Wrocław.

Wiśniowski E.

1988 Kościół na ziemiach polskich w średniowieczu, [w:] Historia Kościoła, t. 2, red. L. Rogier, R. Aubert, M. Knowles, Warszawa, s. 417-465.

Wojenka M.

2016 Jerzmanowice-Stara Wieś. Nowo odkryta warownia średniowieczna na Wyżynie Krakowsko-Częstochowskiej, [w:] Od Bachórza do Światowida ze Zbrucza. Tworzenie się słowiańskiej Europy w ujęciu źródłoznawczym. Księga jubileuszowa Profesora Michała Parczewskiego, red. B. ChudzińWyrozumska B.

ska, M. Wojenka, M. Wołoszyn, Kraków-Rzeszów, s. 663-673.

1977 Drogi w ziemi krakowskiej do końca XVI wieku, Wrocław. Wyrozumski J.

1977 Jan Muskata, Polski Słownik Biograficzny, t. 22, z. 93, s. 291-295. Zagórowski O.

1960 Lipowiec, zamek biskupi i dom poprawy dla księży, NP, t. 12, s. 173-220.

Zajączkowski S.

1968 Opole chrobskie i poczatki Pabianic, [w:] Dzieje Pabianic, red. G. Missalowa, Łódź, s. 7-25. 
Żaki A.

1964 Nowo odkryte grodzisko w Kurowie, pow. Nowy Sacz, Acta Archaeologica Carpathica, t. 6, s. 41-46.

\section{ON THE RESEARCH PROBLEMS OF THE CASTLES OF BISHOP JAN MUSKATA IN KRAKOW LAND}

Keywords: Bishop of Krakow, Jan Muskata, Lesser Poland, Venceslaus II, territorial authority, castles.

Summary

The goal of the article is to characterise the defensive construction of Bishop of Krakow Jan Muskata in Krakow Land, which - to date - has not been thoroughly studied, even though the researchers pointed out to such a necessity. Historians' analysis of written records combined with the results of archaeological excavations enable the identification of structures which were extended or erected by the aforementioned bishop. These complexes can be divided into two categories. The first one constitute castles located in important estates (Sławków, Lipowiec, Muszyna, Przymiłowice). The second category constitute the so-called robbery castles (Ostrężnik, Birów, Kurów, Sułoszowa, Biśnik, Grodzisko Pańskie) erected during the period of holding the Starosta of Lesser Poland office by Jan Muskata and the collapse of the Bohemian authority. These were complexes with a military function, built in the area of the Kraków-Częstochowa Upland and Sądecczyzna. One of the main merits of the Bishop in the field of foundation of defensive architecture activity is the introduction and dissemination of the first masonry elements in many fortified structures, which is extremely important in the context of the beginning of stone castles in Lesser Poland. The goal of all these foundations was first of all to strengthen and to maintain the power of Venceslaus II, whose ally was Muskata, as well as to create an independent bishop duchy in Krakow Land. 